I-Pop: International Journal of Indonesian Popular Culture and Communication

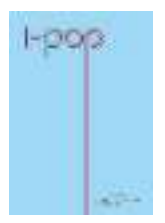

Vol. 1(1) pp. 1-12, (2020) DOI: I0.36782/i-pop.vlil.34

\section{Perpetuating Stigma: Representation of Widows and Divorcees (Janda) in Indonesian Popular Media}

\author{
Iwan Awaluddin Yusuf ${ }^{*}$
}

\begin{abstract}
The image of widows or divorcees (janda) has been negatively portrayed in the various forms of Indonesian popular media. Media critics have shown that media representation contributes to the spread of inaccurate and misleading ideas about janda in societies. This paper discusses the representation of widows and divorcees in mainstream Indonesian films, songs, and news coverage. Through qualitative content analysis of selected Indonesian films, dangdutsongs, and news coverage using the word "janda" in the title, this study revealed that stigmatisation continues to occur. It found that janda are often depicted stereotypically across film genres. The appearance of janda in Indonesian film is accompanied by its typical attributes, such as "beautiful", "rich", "young", and "seductive". The negative representation of janda also found in dangdutsongs. Through the title and lyrics, those songs often associate janda as inferior, powerless, or conversely, predatory and sexually seductive. News coverage depicting widows and divorcees, which should be based on facts was found to be excessively biased due to the addition of the journalist's personal opinion.
\end{abstract}

Keywords

widow, divorcee, janda, representation, Indonesian media

To cite this article ( $7^{\text {th }}$ APA style):

Yusuf, I. A. (2020). Perpetuating Stigma: Representation of Widows and Divorcees (Janda) in Indonesian Popular Media. I-Pop: International Journal of Indonesian Popular Culture and Communication, I(I), I-I2. http://doi.org//0.36782/i-pop.vlil.34

\section{INTRODUCTION}

In Indonesia, the word "janda" refers to both widows (janda mati) and divorcees (janda cerai). The identity associated with the word relates to all women at the end of marriage, whether by separation, abandonment, divorce or death. Because of the ubiquity of marriage, janda are

'Department of Communication Science, Universitas Islam Indonesia, Yogyakarta, Indonesia 'PhD Candidate from the School of Media, Film and Journalism, Monash University, Australia

*Corresponding author: iwan.awaluddin@uii.ac.id anomalous in Indonesian societies (Parker, 2016). It is associated with the normality of heterosexual marriage in the country, and in various ways janda is the antithesis of the ideal of "ibu", meaning a virtuous wife and mother (Mahy, et al., 20l6). The male equivalent of janda is duda-a widower or divorced man. A duda may be widely considered to be eligible for remarriage, but the term does not appear to result in any of the same negative connotations as janda (Mahy, et al., 2016; Bennet, 2005). At this point, there is a double standard where female janda are considered lower status than male janda. 
Janda suffer from considerable stigma and gender stereotypes in Indonesian societies. Many experience shame and discrimination because of their status. As sexually experienced but single women, they are often suspected of sexual impropriety and become the object of negative gossip, sexual predation from men, sexual jealousy from wives, and general vilification (Parker, 2016, p. 7). Furthermore Parker, et al. (2016) describe that janda is a person who is disadvantaged, frequently poor and a single parent, and discriminated against. They are also subject to suspicion and accusations of moral turpitude (Parker, et al., 2016). Men tend to presume janda are weak and lonely women who can be seduced or simply utilised to satisfy their libido (Zulminarni, 2004). For married women, janda are a threat to the loyalty of their husband and stability of their marriage (Mahy, et al., 2016).

Parker et al. (2016) describes the negative image of janda constructed as immoral representing the opposite of constructions of ideal marriage, female sexuality and gender. However, in their ethnograpghic research, Parker et al. $(2016$, p. 28,30$)$ concluded that janda in Indonesia do not always suffer stigmatisation, some are able to exercise agency to ameliorate their condition and re-establish themselves as respectable women.

The stigma of janda in Indonesia is also pervasive in media representation. This stigmatisation pervades and is reproduced by various Indonesian mass media platforms, folktales as well as by modern pop culture, including songs, films, and novels. In popular culture, they are defamed not only as malicious, greedy, and predatory, but also titillatingly presented for the male gaze and constructed as sexually seductive and promiscuous (Mahy, et al., 20I6; Yusuf, 20I5; Yusuf, 20I2).

The social psychology approach defines stigma as an attribute that marks people as different and causes them to be devalued in society; it is socially constructed and dependent upon both social context and particular inter- personal relationships (Major and O'Brien, 2005, p. 394-6). Parker (2016), highlighted a more operational definition of stigma made by Link and Phelan (200I). There are four conventional components of stigmatisation, including labelling, stereotyping, separation (us and them), and discrimination (Link and Phelan, 200I, p. 367; Parker, 2016, p. 10).

This article analyses the role of Indonesian popular media in portraying janda by utilising qualitative content analysis of selected Indonesian films, dangdut songs, and news coverage of janda. Further the article argues that media representation of janda requires overcoming inaccurate and biased tendencies to end stigmatisation and stereotyping.

\section{METHOD}

This article used qualitative content analysis (QCA). It requires the use of subjectivity values to criticise some potential biases in the representation of janda in Indonesian popular media. The study of representation concerns the construction of meaning. At its most basic level, meaning is constructed through language, signs and symbols, but these processes are never value-free (Kidd, 20I5). For Hall (1997), representation encompasses how language and systems of knowledge production work together to produce and circulate meanings. In this respect, representation becomes the process or medium which meanings of janda are both created and reified.

Content analysis is commonly employed in studies of media representations because it provides a systemic approach for analysing and understanding text-based data (Stemler, 200I). When a researcher is working in an interpretive or critical paradigm, the qualitative content analysis is considered a valuable alternative to more traditional quantitative content analysis (Zhang and Wildemuth, 2009, p. I I). White and Marsh (2006, p. 36) noted that "both qualitative and quantitative content analysis researchers sample text and choose text that is relevant for their purpose, but qualitative researchers focus 
on the uniqueness of the text'. Following those method, QCA does not only produce totals and statistical significance; instead, it uncovers patterns, themes, and categories relevant to social reality (Zhang and Wildemuth, 2009, p. 5). The form and extent of reporting will finally depend on the specific research goals (Patton, 2002).
Furthermore, to explain the sample design, the primary criteria for being included for content analysis was that the media must contain data that will assist a researcher to answer research questions (Krippendorf, 2013, p. II3). This study analyses Indonesian films and dangdut songs that contain term 'janda' in their titles. For the news coverage, samples were

Table I. Widow and Divorcee in Indonesian Film Titles

\begin{tabular}{|c|c|c|c|c|}
\hline Film Title & $\begin{array}{c}\text { Production } \\
\text { Year }\end{array}$ & Director & Genre & Main Artists \\
\hline $\begin{array}{l}\text { Gara-gara Djanda Muda } \\
\text { (Because of the Young Janda) }\end{array}$ & 1954 & L. Inata & $\begin{array}{l}\text { Drama, } \\
\text { Comedy }\end{array}$ & $\begin{array}{l}\text { Ellya Rosa, Ermina } \\
\text { Zaenah, Raden Mochtar }\end{array}$ \\
\hline $\begin{array}{l}\text { Si Janda Kembang (The } \\
\text { Beautiful Janda) }\end{array}$ & 1973 & $\begin{array}{l}\text { Muhardi and } \\
\text { Sudrajat }\end{array}$ & $\begin{array}{l}\text { Drama, } \\
\text { Comedy }\end{array}$ & $\begin{array}{l}\text { Titiek Sandhora, Bambang } \\
\text { Irawan, Hardjo Muljo }\end{array}$ \\
\hline $\begin{array}{l}\text { Gara-gara Janda Kaya } \\
\text { (Because of the Rich Janda) }\end{array}$ & 1977 & Azwar An & $\begin{array}{l}\text { Drama, } \\
\text { Comedy }\end{array}$ & $\begin{array}{l}\text { Nani Wijaya, } \\
\text { Enny Haryono, } \\
\text { Cahyono }\end{array}$ \\
\hline $\begin{array}{l}\text { Sembilan Janda Genit (9 Flirty } \\
\text { Janda) }\end{array}$ & 1977 & $\begin{array}{l}\text { Pietrajaya } \\
\text { Burnama }\end{array}$ & Comedy & $\begin{array}{l}\text { A. Hamid Arief, Zainal } \\
\text { Abidin. Mansjur Sjah } \\
\text { Susanna Caecilia, Ratmi B- } \\
29\end{array}$ \\
\hline $\begin{array}{l}\text { Misteri Janda Kembang } \\
\text { (Mistery of the Beautiful } \\
\text { Janda) }\end{array}$ & 1991 & H. Tjut Djalil & $\begin{array}{l}\text { Horror, } \\
\text { Thriller }\end{array}$ & $\begin{array}{l}\text { H.I.M. Damsyik, Fujiyanti, } \\
\text { Sally Marcellina }\end{array}$ \\
\hline $\begin{array}{l}\text { Kembalinya Si Janda Kembang } \\
\text { (Return of the Beautiful } \\
\text { Janda) }\end{array}$ & 1992 & $\begin{array}{l}\text { Sisworo } \\
\text { Gautama } \\
\text { Putra }\end{array}$ & $\begin{array}{l}\text { Horror, } \\
\text { Thriller }\end{array}$ & $\begin{array}{l}\text { Sally Marcellina, H.I.M. } \\
\text { Damsyik, Eddy Gunawan }\end{array}$ \\
\hline $\begin{array}{l}\text { Ku Tunggu Jandamu (Waiting } \\
\text { for a Divorcee) }\end{array}$ & 2008 & $\begin{array}{l}\text { Findo } \\
\text { Purwono HW }\end{array}$ & Comedy & $\begin{array}{l}\text { Dewi Perssik, Andi } \\
\text { Soraya, Chintyara Alona, } \\
\text { Yana Zein, Fara Diana, } \\
\text { and Edi Brokoli }\end{array}$ \\
\hline $\begin{array}{l}\text { Janda Kembang (The } \\
\text { Beautiful Janda) }\end{array}$ & 2009 & Lakonde & $\begin{array}{l}\text { Drama, } \\
\text { Comedy }\end{array}$ & $\begin{array}{l}\text { Ringgo Agus Rahman, } \\
\text { Luna Maya, Sarah Sechan, } \\
\text { Esa Sigit }\end{array}$ \\
\hline $\begin{array}{l}\text { Darah Janda Kolong Wewe } \\
\text { (The Blood of a Widow } \\
\text { Ghost) }\end{array}$ & $\underline{2009}$ & $\begin{array}{l}\text { Mamahit Luigi } \\
\text { Donie }\end{array}$ & Horror & $\begin{array}{l}\text { Yurike Prastika, Trio } \\
\text { Macan, Mario Pratama, } \\
\text { Shiddiq Kamidi }\end{array}$ \\
\hline $\begin{array}{l}\text { Pelukan Janda Hantu } \\
\text { Gerondong (The Embrace of a } \\
\text { Janda Ghost) }\end{array}$ & 2011 & $\begin{array}{l}\text { Helfi C.H. } \\
\text { Kardit }\end{array}$ & Horror & $\begin{array}{l}\text { Indah Kalalo, Aida Saskia, } \\
\text { Wulan Guritno, Angel } \\
\text { Lelga, Adam Jordan }\end{array}$ \\
\hline $\begin{array}{l}\text { Mati Muda di Pelukan Janda } \\
\text { (Die Young in the Arms of a } \\
\text { Janda) }\end{array}$ & 2011 & $\begin{array}{l}\text { Helfi C.H. } \\
\text { Kardit }\end{array}$ & Comedy & $\begin{array}{l}\text { M. Ihsan Tarore, Ayu } \\
\text { Pratiwi, Shinta Bachir }\end{array}$ \\
\hline
\end{tabular}


conveniently selected of news articles in Pos Kota daily containing the word 'janda'. Pos Kota is an Indonesian daily newspaper published in Jakarta. It is published by PT Media Antarkota Jaya since 1970. Generally, the newspaper contains local, crime, and society news, as well as sports and entertainment news targeted for urban mid-lower-class society.

This research, of course, does not aim to capture the entirety of Indonesian media representation attached to the label janda, but rather choose specific cases in order to explain the pervasiveness of the janda stigmatisation.

\section{FINDINGS AND DISCUSSION}

\section{Image of Jandain Indonesian Films: Reiterating Stereotypes}

The Indonesian film history records many depictions of janda in films, as the lead character of a story (protagonist), the primary opponent of the protagonist (antagonist), and other supporting roles. These films have mostly attended to the stigma attached to janda cerai (divorcee), rather than janda mati (widows). Moreover, most of those films explicitly use the word "janda" in their titles as described in Table I.

The appearance of janda in Indonesian film tends to be accompanied by its typical attributes, such as "beautiful", "rich", "young", and "seductive". In addition, the story development of the janda image is always full of intrigues and mockeries. This causes anxiety for both man and woman. Women feel anxious because they are afraid that her husband/ boyfriend would leave her for the janda.

While for men, they feel anxious because the janda is so attractive, they need to control their desires. Sometimes, the presence of widow or divorcee provides opportunity to release sarcasm and madness to win over other men. In other words, janda seems to become object for other people gossip. This image has been depicted stereotypically in almost every genre: horror, thriller, drama and comedy.

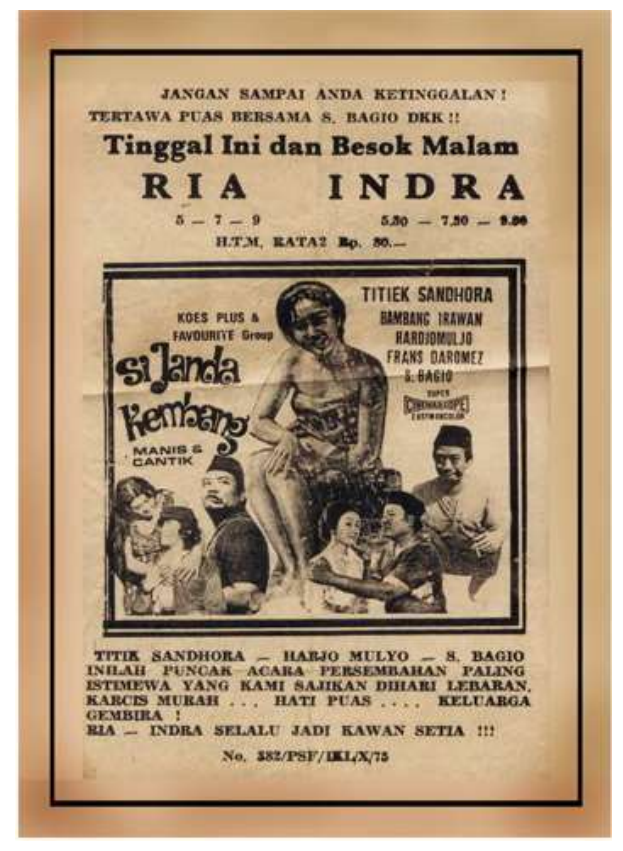

Figure I. The Poster of Janda Kembang (The Merry Widow) Film (source: Supriyono, n.d.)

The most common and stereotypical depiction of young janda in the films is a sexy woman who loves to flirt and dress in a tight dress. This example can be seen in Indonesian film entitled "Ku Tunggu Jandamu" [Waiting for a Divorcee] (2008). Ku Tunggu Jandamu is a comedy movie directed by Findo Purwono HW and starring Dewi Perssik, Andi Soraya, Chintyara Alona, Yana Zein, Fara Diana, and Edi Brokoli. Just like any other films about widow and divorcee, the story in this film exploits the widow and divorcee stereotype: the obsession from the men to win the divorcee's heart.

This movie tells a story of the life of Persik Wulandari (played by Dewi Perssik) after she divorced her husband, Rozak (Eric Scada), who was secretly married to another woman. The court granted the divorce but Rozak would not let Persik go. He did anything to undermine her life so she would come back to him. Things became more complicated when Persik moved in to her sister, Cherry's (Andi Soraya) home. 


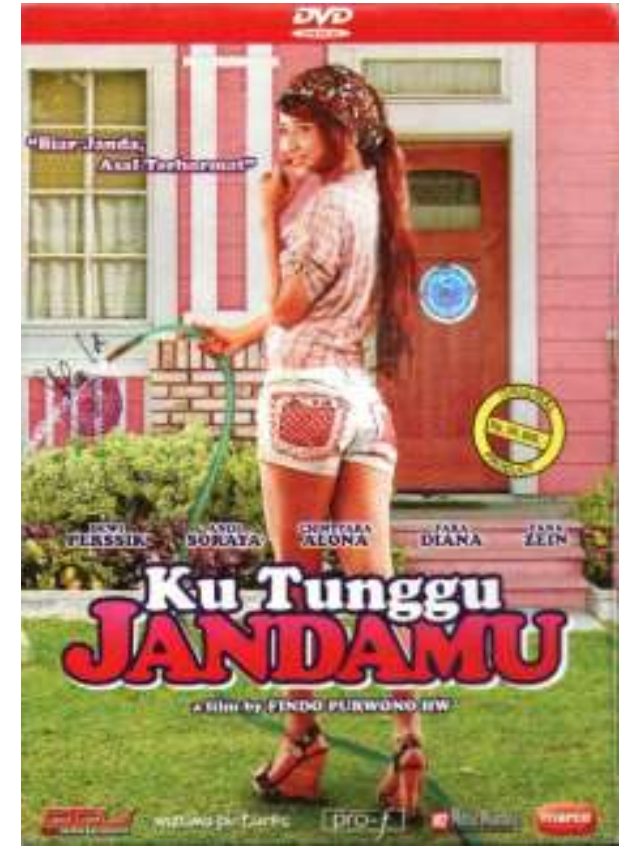

Figure 2. The Cover of "Ku Tunggu Jandamu"

(Waiting for a Divorcee) film (source: bincangmedia.wordpress.com)

Ever since Persik moved to the complex, she created trouble among the residents, as she loved to show her sensuality. Her sexy outfits provoked men to follow and stalk her. Just like the trio (played by Edi Brokoli, Rizky Mocil, and Hardi Fadillah) who often peeped on Persik's private activities such as changing her clothes, taking shower, etc. There was even a scene when Persik wore only underwear. These voyeuristic scenes were portrayed titillatingly in the movie.

Another sensual scene was when Persik relaxed in the terrace and she intentionally opened her skirt to tease her neighbours. This is actually in contrast with the moral spirit of the movie that described in its tagline: "Biar janda asal terhormat" (Be a noble divorcee). 'Ku Tunggu Jandamu' merely lingers over the sensuality of its actress especially Dewi Perssik and Andi Soraya. The film ended with a scene of a contest where Persik was one of the participants and was crowned as the 'Divorcee of the Year' after telling the judges about her struggle to get divorced from her cheating husband.
At this point, the narrative about janda in such films resolves around stereotypes found in society. The myths and stories about janda have a long history in Indonesian oral and written storytelling. Janda has been depicted as either protagonist or antagonist character.

An old folktale of West Sumatra, Malin Kundang for example, portrays a figure of Malin Kundang's mother as a good widow who struggled to raise her kids. Her son Malin Kundang treated her badly in the end. The story itself is about retribution on an ungrateful son who was turned to stone after disrespecting his mother. Malin Kundang is a sailor from a poor family, the protagonist sneaks onto a trading ship, eventually becoming rich, marrying a princess, and acquiring his own galleon. In many versions, the image of Malin Kundang's mother is consistently portrayed as a good widow.

A version of janda portrayal as a bad widow can be found in the folktale of Tangkuban Perahu. The widow in this story is described as a very beautiful woman who could win anyone's heart, including her son who didn't recognize her as his mother due to her everlasting youth and beauty. Unlike the tale of Malin Kundang, the portrait of an evil and flirty widow is consistently represented in almost any version of this story.

Antagonist janda also found in Bali's most famous widow charater, Rangda, a frightening widow-witch who is the main character in the dramatic Calon Arang dance-play (Parker, 2003). In performance, she embodies evil; in everyday life, Rangda and witches in general are said to eat newborn babies and prey upon pregnant women. Such representation suggests that the contemporary suspicion of janda has deep historical, cultural, and mythological roots (Parker, 2003, p. 198; Parker, 2106).

There are numbers of Indonesian literatures on janda, particularly divorcees. O'Shaughnessy (2009) analysed several Indonesian thematic fictions from the late colonial era to recent periods by how they portray janda as good or bad character. 
Meanwhile, a number of popular novels that take young janda as their subject/protagonists published recently, including Janda Perawan by Desi Kirana (2019), Janda-Janda Kosmopolitan by Andrei Aksana (2010), Divortiare by lka Natassa (2008), and Perang Bintang by Dewie Sekar (2006). The representation of janda of these novels have been further developed, partly because gender discourse in Indonesia is perpetually contested and reimagined. However, as in Hellwig's (201 I, p.16) highlight, the stories in many post-New Order fictions were dominated by a situation of divorced parents as a dysfunctional family background. Such representations reiterate the image that divorce destroys family life and is disgraceful.

Regarding this, fictional films or novels as a free narration is merely an extension of the director's or writer's point of view. In one hand, they can deconstruct stereotypes about janda, or on the other hand, reinforce the negative stereotype which has been reproduced in Indonesian society. Stereotypes simplify, reduce and naturalise complex human social identities. Hall (1997) and Talbot (2003) convey that stereotypes are produced and perpetuated through language, naming and the creation of shared understanding of meaning. Stereotypes establish normalcy and may become the basis for marginalisation of certain social groups (Hall, 1997; Talbot, 2003). It 'others' certain identities and makes it normal; to discriminate against them.

Image of Janda in Dangdut Songs: Propagate Objectification

Apart from films, mockeries and stereotypes about widow and divorcee are also easily found in song's lyrics, especially in Dangdut music. The term dangdut is a Javanese language onomatopoeia for the sound of the tabla (also known as gendang) drum, which is written dang and ndut. It was reportedly coined by music magazine Aktuil, although Rhoma Irama stated that it was coined as a term of derision by the rich for the music of the poor (Wintraub 2010).

The term janda is easily found in dangdut songs, both in the lyric and the title such as Mabok Janda (Crazy in Love with Janda), Janda Muda (Young Janda), Janda Tujuh Kali (Seven Times Janda), Gadis Atau Janda (Virgin or Janda), and so on. According to Sundari (2012, p. 24), there are three patterns which are represented in the discourse about widows and divorcees in song's lyrics. Those patterns are: janda as object (objectification of janda), men as those who objectify janda, and popularity for dangdut genre.

In addition, there is no differences in terms of the singer's gender. The lyrics consistently objectify both widow and divorcee. Below is the lyrics of a dangdut song entitled Janda Bodong (Uncertain Divorcee) by Riana Oces:

Suamiku tergila-gila janda muda beranak dua (My husband is crazy over a young janda with two kids)

Minta ijin berpoligami, aku tak sudi

(He asked me to do polygamy, but I refused)

Gara-gara tak mau dimadu, ia pergi meninggalkanku

(For that reason, he left me)

Tak pernah pulang-pulang lagi, ku sakit hati

(He never come home, l'm broken-hearted)

Bilang tak berani, kau tiru cara sensasi (You said you're afraid, but you're looking for sensation)

Kau talak, kau cerai diriku lewat sms

(You divorce me by text message) Mana kejantananmu, mana hati nuranimu

(Where is your virility? Where is your integrity?)

Kau buang diriku bagaikan baju rombeng

(You dump me like unwanted clothes)

Aku si janda bodong, suami minggat kecantol kalong

(I am the uncertain divorcee, my husband went away for a janda) 
Istri bukan, janda bukan, statusku digantung-

$$
\text { gantung }
$$

(I am no longer a wife, not yet a divorcee, my status is hanging in the air)

Aku si janda bodong, surat cerai kosong melompong

(I am the uncertain divorcee, my divorce paper is empty)

Istri bukan, janda bukan, nasibku digantunggantung

(I am no longer a wife, not yet a divorcee, my status is hanging in the air)

Janda bodong, janda bodong, korban egonya lelaki (Uncertain divorcee, uncertain divorcee, victim of men's ego)

Janda bodong, janda bodong, korban poligami (Uncertain divorcee, uncertain divorcee, victim of polygamy)

(Janda Bodong [Uncertain Divorcee] by Riana Oces)
The above lyrics represent janda as someone who ruins another person marriage because she tempts their husband. Consequently, the couple were informally got divorced, as the wife does not want to commit polygamy. At the end, due to her uncertain status, the wife became an indefinite divorcee and called herself: "Janda Bodong".

The number of Dangdut songs that depict widow and divorcee represents how society positions them as inferior with negative attributes: flirty, bad luck, seductive, whose on value is as an object of the male gaze. Not surprisingly, most Dangdut songs about widows or divorcees are written by men (Sundari, 2012, p. 24).

This representation cannot be separated from patriarchal culture, which is still strongly rooted in Indonesian society. Thus, the songs (and other media) to be based on this patriarchal view. The fate of a widow with its stereotype, for example, is portrayed in Nasib Janda (The Fate of a Divorcee), a Dangdut song by Elvi Sukaesih.

Table 2. Widow and divorcee in dangdut songs

\begin{tabular}{ll}
\hline Title & Singer \\
\hline Janda Bodong (Uncertain Divorcee) & Riana Oces \\
Janda Kembang (Merry Janda) & Rhoma Irama feat Elvi Sukaesih \\
Janda Muda (Young Janda) & Ade Irma \\
Janda Tujuh kali (Seven Times Janda) & Naya Revina \\
Janda Perjaka (Virgin Janda) & Hati Band \\
Janda Ketemu Duda (When a Duda met a & Mas'ud Sidik feat Rena \\
Janda) & \\
JAMUR/Janda di Bawah Umur (Underage & Cita Citata \\
Janda) & \\
Mabuk Janda (Crazy in Love with a Janda) & Lolita \\
Janda Baru (New Janda) & Dwi Ratna \& Agung \\
$\begin{array}{l}\text { Gadis Atau Janda (Virgin or Janda) } \\
\text { Gadis Atau Janda, versi baru (Virgin or }\end{array}$ & Mansur S \& Elvi Sukaesih \\
Janda, new version) & Nita Thalia feat Krisna Mukti \\
Nasib Janda (The Fate of a Widow) & Elvi Sukaesih \\
Janda Kembar Dua (Twin Janda) & Ali Alatas \\
Janda Juga Manusia (Janda is only Human) & Ayunia \\
Janda Minder (Anxious Janda) & Ayunia \\
& \\
\hline
\end{tabular}


Serba salah kalau menjadi janda (It's a dilemma to be a divorcee) Kalau jalan sendiri orang curiga

(People often look at me with anxiety) Paling susah kalau menjadi janda (It's hard to be a divorcee) Karena banyak lelaki memandang rendah (Men often despise me)

Apalagi kalau janda masih muda (Especially when the divorcee is young) Maka banyak yang datang untuk menggoda

(Many people come to tease me) Dan anehnya yang merayu dan menggoda

(Those who tease and flirt) Cuma untuk pemuas nafsu belaka (Only want to satisfy their lust) Memanglah benar janda orang kesepian

(Being a divorcee is indeed lonely)

Tetapi hai janganlah dibuat kesempatan (But please, don't take it as an opportunity)

(Nasib Janda [The Fate of a Divorcee] by Elvi Sukaesih)

The "Nasib Janda" is a song rich in patriarchal nuance. It is about a powerless woman who always afraid of her disadvantaged status as stigmatized janda.

Walby (cited in Lan, 2002) notes that patriarchy is a structured system and social practice, which give power and resources to men who dominate woman. In Indonesia, existing feudalistic culture legitimates this system. This makes the relations between man and woman is hierarchical. Man holds the dominant power causing woman in subordinate position. Patriarchal value can also be reflected in the pattern of life. According to Wolf (1993), if the relationship between men and women is asymmetrical, people are still living in a patriarchal system.

The marriage between repressive and patriarchal norms was absolute. According to Mies (cited in Lan, 2002), patriarchy culture is entrenched in many dimensions of society including popular media. Instead of being reflective about this inequality, media legitimates practices of gender bias and gender inequality through news, ads, songs, films, and other media representation.

\section{Image of Janda in News Coverage: Mixing Fact and Biased Opinion}

Despite the fact that news coverage of widow and divorcee should be objective and relies on facts, the representation of janda in Indonesian news is still considerably biased and opinionbased. Opinion about widow and divorcee often appears in form of generalisation or a jumping to conclusions about widow and divorcee without considering relevant premises, contexts, or facts. The opinion is often constructed as truth or objective fact when it is merely a subjective insight from the journalist. One example of opinion-based news can be seen in the lead of Pos Kota news article below:

Menjadi bom seks tampaknya menjadi pilihan bagi sejumlah selebritis kita yang menyandang status janda. Mereka melihat film dengan buka aurat merupakan bagian dari profesionalisme memenuhi tuntutan skenario. (Pos Kota, August 10, 2008) [Being a sex icon seems to be the only option for divorced and widowed celebrities. They consider this as professionalism to fit in the industry].

Such news coverage type is known as media opining, which can be interpreted as a condition when journalists slip to give their own opinion in news, so facts and opinion collide and real facts blur. This practice is prohibited in journalism by Indonesian Journalistic Code of Ethics. Article three of the code explicitly prohibit mix facts with biased opinion in media reporting: "The Indonesian journalist always verifies information, conducts balanced reporting, does not mix facts with biased opinion, and upholds the presumption of innocence principle."

Therefore, the role of journalist is reporting facts, not giving opinion. This is distinctive from interpretive opinion, which is 
the journalist's interpretation of the facts. Nevertheless, many journalists and editors cannot avoid the temptation to make sensational news by adding their personal opinions and salacious details. An example of media opining, which blends facts and opinions in news, can be seen in a citation from Pos Kota as follow:

\begin{abstract}
"Malang nian nasib janda tua ini. Saat merebus mie di rumahnya...ia terjatuh lalu menyenggol kompor hingga tubuhnya terbakar..." (Pos Kota, July 27, 2004). ["What a poor old widow. While cooking noodle in her house, she accidentally fell, bumped on her stove and got burnt"].
\end{abstract}

The first sentence in the above citation is an opinion from the journalist about how the widow was miserable. The facts and data from the event are mentioned later. The overall news is blurred between news material, opinion, and analysis.

In the digital era of information and media, the negative representation of widow and divorcee remains pervasive. Moreover, this give license to the population to mock janda. For example, a news article entitled "Selebritis Cantik Berstatus Janda" (Gorgeous Janda Celebrities) which was published on Kapanlagi.com, December 19, 2007, received some judgemental comments from the readers. Two of those comments are "aduh... cantik2 ko janda?" (Oh no! How can she be a divorcee when she's so pretty?) and, "gmn klo sm aq aja? pasti tdk q sia2kan...". (How about going out with me? You'll never be wasted).

\section{Perpetuating Factors of Janda Stigmatisation}

The lack of gender sensitivity style of the Indonesian media in covering women could be traced back to the time of the New Order regime In Indonesia (Lan's, 2002; Romano, 2003; Romano's, 1999). The Orde Baru (New Order) regime in Indonesia under the dictatorship of President Soeharto (1966-1998) established a new patriarchal gender ideology, idealising the nuclear family socially engineered with a national family planning program. The government under 32 years of Suharto's leadership was characterised by a repressive political climate and a deep-rooted patriarchal culture. In Indonesia, the patriarchal system was legitimized by the cultural remnants of feudalism in combination with an ideology that dictated the hierarchical relationship of women and men. The position of men was more dominant and influential, while women were in a subordinate position.

Murtiningsih and Advenita (2017) describe that patriarchal culture as embodied in every aspect of life and is typically socialized through religious teachings, embedded values in family, codes of conduct in organisational and employment settings, as well as in the lines of formal, informal and non-formal education. Patriarchal culture leads to difference between the role, position and significance of men and women, both in private and public.

Indonesian society is also imbued concept of "Bapak"-ism, which refers to deference, respect, and obedience towards elders and superiors. Bapakism stems from the term "bapak", which literally means "father". Therefore, Indonesians are socialised to hierarchical structures in which senior men are dominant. Women and youth are subordinates. This patriarchal culture affects the various dimensions of media practices. Indonesian media organisations tend to employ more men than women. Women's voices are lacking in the media sector and organisations, particularly in decision making positions. Consequently, women's perspectives are often underrepresented in media.

A 2012 study about women journalists in the major national media conducted by the Alliance of Indonesian Independent Journalists (AJI) showed that there are fewer women journalists than male journalists in the newsroom at the rate of $1: 3$ or $1: 4$ (Aliansi Jurnalis Independen, 2015, p. 10; Luviana, 2012, 
p. 9). Moreover, only a small number of women journalists occupy strategic positions as decision makers in media organisations.

Furthermore, Parker (2016, p. 17) outlines the two main pillars of the New Order were developmentalism and political stability. Even though development, by its very nature, implies tremendous social change, the regime had a socially conservative ideal: a stable and peaceful society, based on the harmonious nuclear family built on patriarchal gender relations (Parker, 2016, p. 17). Because of such idealized married women and mother, janda are anomalous in Indonesian societies. The stigmatisation constructs the janda as disgraced and immoral.

The stigmatisation could also arises because janda have no male to dominate and discipline them. This condition provides some levels of independence from male control that makes them so dangerous-dangerous to the patriarchal system. On the one hand, they are older and have experience, not just life experience but also sexual experience and power which might be frightening for some men and at the same time really exciting.

On the other hand, older experienced women are less able to be controlled-as they have maturity and confidence on their side. Such a cohort of independent women maybe damaging to patriarchy, so they must be controlled in another way, through the stigmatisation. This is how societies disciplines them and controls their power.

\section{CONCLUSION}

The stigmatisation of janda in Indonesian popular media has been perpetuated through stereotyping, labelling, and objectification. The stigmatisation constructs the janda as disgraced and immoral, in contrast to the idealized married women and mother. Perpetuating stigma in the media and popular culture disregards principle of gender-sensitivity and ignores the fact that women often face difficult choices in their life when divorce is the best and only solution. The fate of people's intimate relationships is also diverse and should not be expected to follow one model. Stigma is not just a part of social interaction or an attribute of an individual, it assaults at the heart of the individual's value as a human being.

While this paper's focus is on Indonesian films, dangdut songs, and news coverage of janda, the findings deliver insights into the criticisms of media representation of janda and the effects on janda in Indonesian society. The negative images associated to janda have harmful consequences for widows and divorcees in the country. Negative media representation about janda contributes to the perpetuating stigma. Despite the fact that the problem of stigmatisation of janda may be systemic, media--and the people behind the media--should take a role in the process of de-stigmatisation and deconstructing stereotypes and myths about janda.

\section{Acknowledgement}

I would like to thank Dr. Sara Niner from Monash University who provided insight and expertise that assisted in improving this manuscript.

\section{References}

Aliansi Jurnalis Independen (20I5). Indikator sensitif gender untuk media: Kerangka indikator mengukur sensitivitas gender pada organisasi dan konten media [Gender-sensitive Indicators for media: Framework of indicators to gauge gender sensitivity in media operations and content]. UNESCO and AJl Indonesia.

Bennett, L. (2005). Women, Islam and modernity: single women, sexuality and reproductive health in contemporary Indonesia. Routledge.

Hall, S. (1997). Representation: Cultural representations and signifying practices. Sage Publications.

Hellwig, T. (20l I). Women writing about marriage and sexuality: Post-1998 Indonesian fiction. Asia Research Institute.

Kidd, J. (2015). Representation. Taylor \& Francis Group. https://ebookcentral-proquestcom.ezproxy.lib.monash.edu.au 
Krippendorff, K. (20/3). Content analysis. An introduction to its methodology, $3 r d$ ed. Sage Publications.

Lan, M. (2002). Pers, negara dan perempuan: Refleksi atas praktek jurnalisme gender pada masa orde baru [Press, State and Women: Reflections on the Practice of Gendered Journalism in the New Order]. Kalika, Yayasan Adhikarya IKAPI and Ford Foundation.

Link, B. G. \& Phelan, J. C. (200I). Conceptualizing stigma. Annual Review of Sociology 27, 363-85.

Luviana. (20I2). Jejak Jurnalis Perempuan: Pemetaan Kondisi Kerja Jurnalis Perempuan di Indonesia. [The Trace of Women Journalists: Mapping the Working Conditions of Women Journalists in Indonesia]. Aliansi Jurnalis Independen.

Mahy, P., Winarnita, M. and Herriman, N. (20/6). Presumptions of promiscuity: reflections on being a widow/ divorcee from three Indonesian communities. Indonesia and the Malay World 44(128),

47-67. http://doi.org/ I0.1080/I36398 I I.20 I5. I I00872

Major, B. and O'Brien, L. T. (2005). The social psychology of stigma. Annual Review of Psychology 56, 393-42I.

Murtiningsih, B. S. E. and Advenita, M. (2017). Representation of patriarchal culture in new media: A case study of news and advertisement on Tribunnews.com. Mediterranean Journal of Social Sciences, 8(3), 143-154. http://doi.org// 0.590I/mjss.20I7.v8n3p|43

O'Shaughnessy, K. (2009). Gender, state and social power in contemporary Indonesia: divorce and marriage. Routledge.

Parker, L. (2016). The theory and context of the stigmatisation of widows and divorcees (janda) in Indonesia. Indonesia and the Malay World, 44(I28), 7-26. http://doi.org/I0.1080/I36398 I I.20 I5. I I00863

Parker, L., Riyani, I. and Brooke, N. (2016). The stigmatisation of widows divorcees (janda) in Indonesia, and the possibilities for agency. Indonesia and the Malay World, 44(I28), 27-46. http://doi.org/ I 0.1080/ | 36398 I I.2016. I I I 677

Parker, L. (2003). From subjects to citizens: Balinese villagers in the Indonesian nation-state. Routledge.

Patton, M. Q. (2002). Qualitative research and evaluation methods, 3rd ed. Sage Publications.

Supriyono, D. (n.d). Poster Film Jadoel. Warung Barang Antik. http://warungbarangantik.blogspot.com/ 2010_08_0l_archive.html

Romano, A. (2003). Politics and the press in Indonesia: Understanding an evolving political culture. Routledge Curzon.

Romano, A. (1999). Journalistic identity and practises in late New Order Indonesia (Unpublished Doctoral's Dissertation). Queensland University of Technology, Australia.

Stemler, S. (200I). An overview of content analysis. Practical Assessment, Research \& Evaluation 7(17), |37-| 46.

Subono, N. I. (2003). Menuju jurnalisme yang berperspektif gender [Toward gender-sensitive approach in journalism], Jurnal Perempuan, 28(I), 55-66.

Sundari, A. (20I2). Nasib Janda: Representasi janda dalam lagu dangdut [The fate of janda: Representation of janda in dangdut song]. Rifka Media, 5(I), 24.

Talbot, M. (2003). Gender stereotypes: reproduction and challenge. In Janet Holmes and Miriam Mayerholff (eds), The handbook of language and gender. Blackwell.

Wolf, N. (1993). Fire with fire: New female power and how it will change the twenty-first century. Random House.

Yusuf, I. A. (20I2). Janda dalam Bingkai Media [Media Framing on Widows and Divorcee]. Rifka Media, 5(I), 19-24.

Yusuf, I. A. (20I5). Eksploitasi Sosok Janda dalam Produk Media dan Budaya Populer [Exploitation on Widow and Divorcee in Indonesian Media and Popular Culture]. Proceeding 2nd Conference on Language, Linguistic \& Literature (COLALITE) 2015 (pp. 2 I5-228). Purwokerto, Indonesia, November 21,2015

Weintraub, A. N. (2010). Dangdut Stories: A Social and Musical History of Indonesia's Most Popular Music. Oxford University Press.

White, M. D. and Marsh E. E. (2006). Content Analysis: A Flexible Methodology. Library Trends, 55(10), 22-45. http://doi.org/ 10.1353/lib.2006.0053

Zhang, Y. and Wildemuth, B. M. (2009). Qualitative analysis of content. University of Texas. https://www.ischool.utexas.edu/ yanz/Content_ analysis.pdf

Zulminarni, N. (2004). A journey to the world without a husband. In Afrida Purnama et al. (eds), 
(C) 2020 I-Pop: International Journal of Indonesian Popular Culture and Communication, Vol. I No. I (February-June)

Sebuah dunia tanpa suami [A world without a husband]. Seknas Pekka-PPSW.

\section{Notes on Authors}

Iwan Awaluddin Yusuf is a senior lecturer and researcher at the Department of Communication Science, Universitas Islam Indonesia, Yogyakarta Indonesia. His research focuses on journalism studies, media and gender studies, digital media, and superhero studies. E-mail: iwan.awaluddin@uii.ac.id; iwan.yusuf@monash.edu. 